\title{
Why is it so Difficult to Maintain Loving Relationships? Are these Difficulties linked to the Intolerance of Otherness and to the Famous "No, No!" of Childhood?
}

\author{
Ronnie Solan* \\ Department of Psychology, Tel-Aviv University, Israel
}

Submission: October 12, 2016; Published: November 22, 2016

*Corresponding author: Ronnie Solan, Department of Psychology, Lecturer in Tel-Aviv University, 40 Tagore st. Tel-Aviv, 6920342, Israel, Tel: +97254-484-8204; Email: ronnie.solan@gmail.com

\begin{abstract}
Ronnie Solan, PhD identifies the difficulties of maintaining love relationships as having roots in childhood experiences. Solan views these difficulties as beginning between parent and child relationships, as continuing within couples, and then manifesting in the family. Infinite memory traces and childhood experiences profoundly impact our life as adults and couples. Some of them are related to love relationships, to intimacy, respectfulness of each other separateness etc., and others are related to frustrations, anger, injuries and trauma in the relationships. Spouses are repeatedly willing to destroy their love relations when they find themselves in such Narcissistic struggle linked to sensations of injury, jealousy or betrayal and unbearable otherness. How is it possible to avoid the destructiveness of partnerships and love relations that arise from intolerance of the other's separateness and otherness and increase positive childhood memory traces of love relationships, intimacy and respectfulness?
\end{abstract}

Keywords: Healthy Narcissism; Immune System; Child Development; Jointness; Parenting; Object Relations; Child Psychology

\section{Introduction}

Freud, in his masterpiece Civilization and its Discontents [1], wrote about how and why it is so difficult to keep civilization's rules and values intact and thus avoid rebellion, corruption and wars [2]. From infancy onward, there occurs a continual process of attachment [3] and disconnecting, of love and hate, intimacy and struggling $[4,5]$, separating and joining and of transference of childhood's attachment as well as transference of childhood's disconnecting [6]. Still, the need for love relations in jointness [7] and to be loved as one is in his individuality, remains generally a key source of happiness and represents the deeper, continual and powerful urge of most of us across the lifespan. While the first year of life (the oral stage) is characterized essentially by loving relationships and intimacy (between parent and baby), the second year (the anal stage) may be characterized essentially by struggles - negotiation culmination in love relations between two autonomous beings $[8,9]$. Both parents and toddler, like any couple, are driven to preserve their familiar sense of intimacy, love $[10,11]$ and separateness $[8,7]$ but at the same time each encounters otherness in his partner, which causes him to feel injured. Now, both parent and toddler are striving for love, but are also ready to fight against this otherness in order to preserve their familiar sense of Self autonomy. They are ready to struggle at any hint of divergences between them as if they totally lost that very love they wish to preserve. Unfortunately, this childhood struggle between two narcissistic autonomies continues (often as a transference) [6] in adulthood between spouses [12].

It is a struggle between two narcissistic autonomies which threatens the maintenance of a love relationship between them. Often spouses are disconnected from each other in these moments until one of them (or neither) initiates reconciliation. They test the limits of each other, they come to understand to what extent each one will tolerate the struggles, and in doing so, they may choose (consciously or unconsciously) to struggle or initiate reconciliation. From the anal stage, the stage of ambivalence, the bonding in intimacy is often transformed into a struggle by the toddler's need to assert his separateness, 
individuation and autonomy. The toddler expresses contrariness by asserting" No, No" or "I want" or "I against you, I versus you." [13].This is often followed by an explosion of aggression [1417]. Then, there again emerges the need for refueling by love (between child and parents). The sense of familiar individuation is consolidated by this combination of self-assertion and love refueling $[18,19]$ in intimacy.

In my book, The Enigma of Childhood - The Profound Impact of the First Years of Life on Adults as Couples and Parents [8], I elaborated this emotional shift between bonding in intimacy and self-assertion of separateness as resulting of the processing of the Emotional Immune System. In my view this innate emotional immune system-representing the functioning of healthy narcissism-operates to safeguard the familiarity and the wellbeing of the self against invasion by foreign sensations [20]. This immune system also triggers narcissistic resistance or rejection of any strangeness or otherness challenging the familiar sense of the Self.

The immunization vacillates between attraction to the familiar and resisting/rejection of that which is strange or novel, in other words, between well-being in the presence of the familiar and alertness upon facing strangeness. The processing of the emotional-narcissistic immune system is very similar to those of the body immune system. Narcissistic immune processing of the familiar sense of the Self represents a collection of phenomena like intimacy, love relations, love refueling, happiness, resistance, rejection, transference [6], hate [21,22] trauma, racism and destructive impulses. In these crucial moments of facing the otherness in our loved objects, the individuals are pushed unconsciously to annihilate their precious love relationships as if they were suffering life's threatening or an allergic response to the stranger $[8,20,23]$. Thus, it is certainly much easier to destroy relationships than it is to recreate them.

\section{A short background concerning love relations}

The first year of life, from birth up to one year, named the oral stage by Freud [24] is in my view the most important archaic network of intimacy and love relations [25,11]. Memory traces from archaic object relations experiences such as intimacy, love and happiness reverberate across a lifetime. Preservations and reverberations are made possible by the operation of healthy narcissism [8] as a form of emotional immune processing of these fundamental experiences. Reverberations of these archaic experiences motivate us to reproduce endlessly this sense of a familiar experience $[26,27,10]$ as milestones of life and happiness, often through transference on new objects [6]. According to my understanding, these healthy love memory traces represent not love relationship in "oneness" as many of us psychoanalysts and psychologists consider [28,11] but as jointness-separateness [7].

I conceive normal object relations as jointness between separateness founded on the innate narcissistic attraction (of both) to the familiar in this loved object recognized as a familiar not me, as non-self or as the otherness in the familiar. This attraction to join the familiar object is combined with another "fundamental narcissistic needs to preserve a sense of oneself as an autonomous individual" [21]. During the intimacy that characterizes jointness relations between parent and baby (or any spouses), emerge in each the narcissistic need to experience the approval of the loved ones and to be loved as we are, each within the boundaries of his or her own self-familiarity. Only then, sensations of separateness and boundaries are temporarily blurred in their shared space of love relationships and feelings of love, intimacy and happiness flood them both. Subsequently, they communicate signs of separation followed by the restoration of separateness and otherness between self and his object.

Self-familiarity is thus preserved in separateness, complemented with the gradual acquisition of recognition and tolerance toward the otherness of one's love objects. In my view, the parents' support, attune and respect for their child's separateness, his own (otherness) needs - is crucial for the child's narcissistic immunization of his true self-familiarity in separateness and his self-esteem. At the same time the parental capacity to experience intimacy with the baby as a separated object, love him as he is, strengthens the baby's capacity for joining between separate individuals in a shared space where feelings of intimacy, love relations and happiness take place. Balint [29] emphasizes the difference between primitive pregenital infantile love and mature love. Balint notes that in primitive love the object's interests, sensitivities, or wellbeing are not considered; the object is taken for granted as always satisfying his needs. We encounter such form of oral love when experiencing infatuation. When the infatuation [30] fades, suddenly the previously-infatuated individual doesn't understand why he so much idealized his partner and yet now feels so disappointed with him/her. The passage from idealization to devaluation is unbearable.

Balint also claims that "a healthy man must be able both to love and hate. In health hate should, like acute anger, be easily and speedily dissipated if the situation changes." This Balint's important statement is indicating, in my view, on the psychodynamic which takes place in the anal stage (from about one year and six months of age). The anal stage represents the assertion of the child's "No, No" or "I want alone" which motivates a new form of love relations; both are now obliged to consider the other, and also to consider his aggression or hate beside the love attachment $[8,21,10,31]$. The toddler may enjoy willingly giving or bestowing some of his assets to his loving parents, or he may use them for struggling or in negotiation with them. He can initiate their smiles and loving expressions and he can provoke their anger and even worry. The toddler feels as if he can do everything alone and yet still he often goes to his parent to have a hug and kiss as means of refueling the love within the relationship. At the same time the parents love and encourage 
their toddler autonomy while as human beings, they also are often upset by his behavior, sometimes narcissistically injured by him, and even feel helpless when they try to motivate him to obey them. Following this they might feel guilty or ashamed, as though they are bad parents. They may even feel as though they have a bad child. From this stage of life, these compounded relations accompany the parents and infant each along his lifespan.

Consider, for example, these two feelings that appear to be opposed in the context of a love relationship: the desire for exclusive intimacy with the object and the desire for autonomy. Presumably, these two opposed feelings can be integrated when both partners are able to tolerate the otherness and separateness of the other. Gordon's research prompts him to claim that ". People unconsciously repeat their past attachments for better or worse" [10]. It occurs, in my view, because these compound emotional experiences of the first years of life leave memory traces that reverberate incessantly - as a processing of narcissistic immunization of the sense of familiarity - and thus impact profoundly over the course of a lifetime. From the oral stage, through the anal stage and onward, we try hard to maintain a good-enough balance between these antagonistic needs, between jointness and separateness [7], between connecting with others in love relationships and the willing to disconnect due to the triggering of frustrations, criticism, hate $[8,32,33]$ and intolerance to the otherness of our partner (parent, child or spouse). Gordon [10,12,34] claims that "research showed that love is by far the most important resource in people's lives. It relates most to happiness. Love plays the biggest role in forming values that guide life choices and lifestyles. The data supports the importance of childhood experiences in the quality of life [10]."

Gordon also adds that, according to his research, "Someone who experiences a shortage of love in childhood is likely to have unhappiness as an adult, or they later were selfdefeating in getting the love they needed." [10]. Parental disappointment, criticism, shaming rejection and abandonment or else might accentuate the child's false self, explosion of aggression, intolerance toward each other's otherness and often disconnecting of love relationships [8,14,11]. Winnicott [35] stresses clearly the difference between the true self as a normal development of the self while the false self indicates on distortion of this improvement [35]. Torsti [36] reminds on resistance that "sometimes has its source in early traumatization". We also know that people who are easily flooded by emotionality tend to express aggression toward their love object instead of love expression in order to (unconsciously) avoid or denial their "flooding" emotionality. As well, people who suffer from narcissistic personality or any pathological narcissism [37] tend to express insatiable demands, they deny the presence of the other with whom they desire intimacy, they are extremely intolerable to any hint of otherness and they are quickly injured by the otherness.
They are happy only when they feel as though they are unseparated from their object and as if share a sense of bodily oneness with the other. In any case, love relations that represent mutuality and reciprocation are not possible for them [11] and they are willing to disconnect relationships immediately. This basic data from childhood experiences might clarify how pathological narcissism immune ironically the familiar sense of the (false) Self as un-separated through endlessly repeating unhappiness experiences and feelings of low self-esteem [8]. We have to remember that each of the spouses has his own narrative of life. Each is profoundly impacted by his own early experiences which he transfers on. Moreover, each of them wishes their spouse to join him in reviving the echoes of his own memory traces. We are all attracted to the familiar from our childhood, we are all narcissistically injured by the other who neglects or criticizes our familiarities and we tend to resist/reject otherness and strangeness.

Let us have a look on psychodynamic relations of one parental couple. Both parents of Ben (at two-and-a-half) are very devoted to their children. They express love often and they convey sense of family stability and security. There is a good atmosphere at home. However, as always between spouses, each of them has his/their own subjective outlook on life, according to the echo of his childhood memory traces. Ben's mother wants to "liberate" her child and allow him to express his individuality. She tries to be tuned to his separateness. She feels that she knows him well enough. She encourages him to dare and go up to the trampoline and to play alone, even if she can't see clearly where he is. She remembers that her own father was like this with her. She liked his confidence in her and she felt as though he were proud of her. Nevertheless, sometimes she remembers thinking that maybe he didn't really care about her wellbeing. Now, she begins to wonder what Ben is feeling.

Ben's father, however, is really scared of his partner's attitude and they quarrel about it in front of Ben. The father shouts at the mother that she is a bad mother that neglects her son, and says that something terrible might happen to him. The mother shouts back at the father, asserting that he is a coward, and she doesn't want her son to be a coward like him. Neither is capable of respecting the otherness of their spouse, to enable each to be with the child as he feels familiar with in his true self. Although the mother tries to respect her child's separateness, she fails to do it toward her spouse. Each wants to program the other according to his familiar sense of his Self. Their loving relationship is frequently placed under strain and they find it difficult to recreate their partnership.

\section{The toddler}

Ben (at two-and-a-half) is going to the park with his father. He feels really happy with his father. He immediately wishes to show his father his autonomy and all his new mobility achievements that he experienced the previous day with his mother. He wishes to demonstrate to his father his omnipotent 
power by saying, "Look, Pa, I'm jumping" [on the trampoline]. His terrified father shouts, "Ben stop! You'll fall on your neck." Ben is offended and angry, as if his entire body self-image and autonomy were under attack, and he is prepared to mobilize all his narcissistic power to protect his wounded self-familiarity. He responds, "I'm jumping." Now the father's sense of authority, representing his self-familiarity, is jeopardized by his little boy's otherness, and he is prepared to mobilize all his narcissistic power to protect his wounded self-familiarity. The father shouts louder: “No. If I say no, you won't do it; don't you dare." "Yes I will," Ben replies.

Father and his child are both pulled into a position where each is preoccupied by restoring his injured self-familiarity autonomy at the cost of losing their intimacy and love relations. Ben is angry and wounded, he doesn't want to obey his father's interdiction while the day before he was so proud to do the very same activity with his mother. The feeling of having a coward father, as his mother labeled him, is unbearable. They confront each other in an upsetting battle over separateness, a struggle of narcissism versus narcissism (NVN). Each is injured by the otherness of his partner; each confronts the otherness of his beloved one, who is now experienced as a rival and as a stranger. Father and his child are both drained and hurt. The resistance continues until the more mature of the two, the father, succeeds to comprehend the farcicality of the situation. He embraces his beloved son, hugs and kisses him, and suggests another game.

Ben is delighted; he runs to his father's arms to be hugged as if to be refueled by his love. The battle is over by reconciliation, love take place, and they both feel again partners in their shared space. Each has restored his self-familiarity and objectfamiliarity and has recovered his self-control. Some minutes later, the father feels that they have both enjoyed themselves, overcome their wounds, and that it is time to separate from the park and go home. Father says: "Ben, my dear, it's time to go home. Let us decide on three more things to do and say 'bye bye' to the park." Ben concedes without a quarrel. As they go home, they laugh and feel bonded to one another. At home Ben's father says, "I have some work to do now, my sweetheart. What do you want to do now?" Ben replies, "I'll play with the play mobile." Each move to his own self-space and each will elaborate through his memory traces, albeit unconsciously, the struggle of Narcissism versus Narcissism that they experienced as manifested through the father's worries and Ben's wounds of autonomy.

These reverberations will also include their reconciliation, refueling of love and beneficial separation. The struggle between spouses is often inevitable as it is triggered by the narcissistic injury of each facing the otherness of his partner. Feeling upset and anger is also inevitable; yet expressing the need to be refueled by love is necessary to balance love and hate: Children repeat and ask the parent "Do you love me?"; "Tell me that you love me". May parent or even the toddler (one of them or both) have enough self-control and memory traces' reverberations of love, peace and happiness in order to reconciliate? [38]. Will spouses dare to express this essential need to be refueled by love in order to maintain a balanced love relationship, which I named "the ART of Couple hood", or will they be shame to disclose this archaic need while reverberations of the "evil" otherness (often resulting of transference) push them to destruct and disconnect their love relationships?

\section{Conclusion}

Infinite memory traces and childhood experiences profoundly impact our life as adults and couples. Some of these memory traces are related to positive love relationships, intimacy and respectfulness and others are related to frustrations, anger, injuries and trauma in the relationships. These normal forms of childhood narcissistic struggles experiences continue to emerge across the lifespan and often threaten the capacity of many individuals to maintain love relationships and happiness. Unfortunately, sensations of injury, jealousy or betrayal seem to have a stronger impact on love relations than refueling by love, reconciliation and tolerance toward the otherness. Can we prepare our children to live together, to enjoy partnership and to maintain love relations and intimacy so that they will have a positive impact on their future couple hood? Can we assist their tolerance of the inevitable narcissistic injury, rivalry and aggressiveness?

Can we increase their need to find ways to be refueled by love as well as increase their respect toward the otherness of their beloved one? Finally, can we emerge in our children a familiar sense of love relations that from time to time are exposed to injury and quarrel but finally terminate via refueling by love, negotiation and reconciliation?. Refueling by love and reconciliation after fighting might enhance the balance in love relationships, increase the tolerance toward the otherness, negotiation with the other and creative communication with him; frustration, injury and aggression might thus be expressed while endured; and the disconnecting of the love relationships can be prevented. That is what I named by the ART of couple hood.

\section{References}

1. Freud S (1930) Civilization and its Discontents. Hogarth, UK, 21: 59145.

2. Freud S (1933) Why War? Hogarth, UK, 22: 197-215.

3. Bowlby J (1988) A Secure Base: Parent-Child Attachment and Healthy Human Development. Basic Books, USA.

4. Kelly VC (2012) The Art of Intimacy and the Hidden Challenge of Shame. Maine Authors Publishing, USA.

5. Kelly VC (1996) Affect and the redefinition of intimacy. In: DL Nathanson (Eds.).

6. Harry M Anderson (2011) From an Art to a Science of Psychoanalysis: The Metapsychological Formulation Method. Trofford publishing.

7. Solan R (1991) "Jointness" as integration of merging and separateness in object relations and narcissism. Psychoanal Study Child 46: 337352. 
8. Solan R Gaoni B (2015) The Enigma of Childhood - The Profound Impact of the First Years of Life on Adults as Couples and Parents; Karnac, London.

9. Freud S (1918) From the History of an Infantile Neurosis. The Standard Edition of the Complete Psychological Works of Sigmund Freud, Volume XVII (1917-1919): An Infantile Neurosis and Other Works 1-12.

10. Robert Morris Gordon (2006) An Expert Look at Love, Intimacy and Personal Growth. Selected Papers in Psychoanalytic Social Psychology. Library of Congress, USA.

11. Kernberg OF (1995) Love relations: Normality and Pathology. CT: Yale University Press. New Haven, US.

12. Gordon RM (2007) I love you madly! Workbook: Insight enhancement about healthy and disturbed love relations PA: IAPT Press, Allentown, US.

13. Heimann P (1965) International Journal of Psychoanalysis. XLIII, 1962: Notes on the Anal Stage. Pp. 406-414. Psychoanal Q 34: 307-307.

14. Freud S (1908) Character and Anal Eroticism. S. E. Hogarth, London, UK, 9: 169-175.

15. Schlomer GL, Del Giudice M, Ellis BJ (2011) Parent-offspring conflict theory: An evolutionary framework for understanding conflict within human families. Psychol Rev, Vol 118(3): 496-521.

16. Bernstein (2013) Anger: Impulse and Inhibition-Impressions and Reflections of a Modern Analyst. Modern Psychoanalysis 38(1): 76-87.

17. Josephs Lawrence, McLeod, Barbara Ann (2014) A Theory of MindFocused Approach to Anger Management. Psychoanalytic Psychology 31(1): 68-83.

18. Mahler MS, Pine F, Bergman A (1975) The psychological birth of the human infant. Basic Books, New York, USA.

19. Brent Laura, Resch Ruth C (1987) A Paradigm of Infant-Mother Reciprocity: A Reexamination of "Emotional Refueling". Psychoanalytic Psychology 4(1): 15-31.

20. Solan R (1999) The interaction between self and others: A different perspective on narcissism. Psychoanal Study Child 54: 193-215.

21. Gabbard GO (1993) On hate in love relationships: The narcissism of Minor differences revisited. Psychoanal Q 62(2): 229-238.

22. Rosenberg R (2013) The Human Magnet Syndrome: Why We Love People Who Hurt Us. Pesi Publishing and Media.

23. Britton R (2004) Subjectivity, objectivity and triangular space. Psychoanal Q 73(1): 47-61.
24. Freud S (1917) An Infantile Neurosis and Other Works, Hogarth, London, UK, 1-287.

25. Britton RS (1997) Love Relations: Normality and Pathology. By Otto F Kernberg, Yale University Press, 1995, New Haven, USA.

26. Sigmund Freud (1914) On Narcissism: an Introduction. S. E. Hogarth, London, UK, 14: 69-101.

27. George J, Levy Y, Shoenfeld Y (1996) Immune network and autoimmunity. Intern Med 35(1): 3-9.

28. Mahler MS, Pine F, Bergman A (1975) The Psychological Birth of the Human Infant: Symbiosis and Individuation. Basic Books, New York, USA.

29. Balint M (1954) On Love and Hate. International Journal of Psychoanalysis XXXIII, Pp. 355-362. (1952) Psychoanal Q 23: 136-137

30. Colman W (1994) Love, Desire and Infatuation Encountering the erotic spirit. J Anal Psychol 39(4): 497-514.

31. Fonagy P, Target M (1997) Attachment and reflective function: Their role in self-organization. Dev Psychopathol 9(4): 679-700.

32. Solan R (1998) Narcissistic fragility in the process of befriending the unfamiliar. Am J Psychoanal 58(2): 163-186.

33. Solan R (1998) The narcissistic vulnerability to change in object relation. In: Psychoanalyse in Israel Theoriebildung und therapeutische Praxis. Rafael Moses (Hg.) Series: Psychoanalytische Blatter, Vandenhoeck \& Ruprecht, Bd. Gottingen, Germany, Europe, 9: 30-56.

34. Gordon RM (2006) What is love? A unified model of love relations. Psychoanalytic Psychology 28(2): 85-89.

35. Winnicott DW (1960) Ego distortion in terms of true and false self. In: The Maturational Processes and the Facilitating Environment. NY: International Universities Press, 1965. New York, USA, p. 140-152.

36. Torsti M (2000) At the Sources of the Symbolization Process: The Psychoanalyst as an Observer of Early Trauma. Psychoanal Study Child 55: 275-297.

37. Ortega-Hernandez OD, Kivity S, Shoenfeld Y (2009) Olfaction, Psychiatric disorders and autoimmunity: Is there a common genetic association? Autoimmunity 42(1): 80-88.

38. Robert A, Moylan LCPC (2015) Spiritual Inner Peace and Happiness with Emotional Core Therapy. Create Space, South Carolina, USA 